PESHAWAR JOURNAL OF PSYCHOLOGY AND BEHAVIORAL SCIENCES, 2017, VOL. 3, NO.1, 95-104

\title{
Socio-Psychological Effects of Emigration on Left Behind Women in Buner
}

\author{
Adnan Khan ${ }^{1}$, Intikhab Alam ${ }^{2}$ and Ubaid ur \\ $\operatorname{Rehman}^{3}$ \\ University of Agriculture Peshawar-Pakistan
}

\begin{abstract}
The present study was conducted to ascertain the sociopsychological effects of emigration on left behind families in district Buner Khyber Pakhtunkhwa. The data was collected from 367 sampled respondents, which were selected from four union councils of four tehsils of district Buner. The data was analyzed by using simple percentages and frequency. The chisquare statistics was used to determine association between independent and dependent variables. The study concluded that wives of emigrants faces loneliness; there was more tension in left behind families; basic needs like emotional needs were not fulfilled; conflict has been develop between spouses; emigration of husband force wives to leave the houses for buying of daily needs, goods; in laws start interference and objections on female outside activities. Moreover, the rate of divorce has not been increased after emigration; emigrant's wives were discriminated by in laws. It is recommended that migrant should increase visiting home or shift their family to abroad to reduce tensions and conflict.
\end{abstract}

Keywords: socio-psychological, emigration and women

The migrants' remittances have the constructive impact on overall economy of Pakistan, i.e. all the institutions like family, households, educational institutions etc. the migration of the labors or other professionals is a good source of earnings (Naseem, 2004). According to Siddidui and Kemel the turn down of remittances has the bad impact on welfare and poverty in Pakistan. The study shows that during nineties in Pakistan the rise in poverty because of the downfall of the remittances.

1M.Phil scholar Department of Rural Sociology, The University of Agriculture Peshawar-Pakistan

2Lecturer, Department of Rural Sociology, The University of Agriculture Peshawar-Pakistan Email: intikhab@aup.edu.pk

3Lecturer, Department of Rural Sociology, The University of Agriculture Peshawar-Pakistan 
Kemel (2001) find out that the remittances downfall is the major cause of affecting in poverty level of Pakistan because of change in income and on the other side the up down of the consumption level and as through increase in capital stock (Javid, Arif, \& Qayyum, 2012).

The phenomenon of migration was practice since the time immemorial. Man has been practicing migration from ancient time for the better food, living and protection. Sometimes they have to migrate to avoid persecution, harassment and sometime in search of better opportunities. The term migration came out from Latin word which means is to change one residence or place and community. Migration refers to the process in which people left their place of origin and adopt to live in other place or country. It is an agent of social change, where it tends to vary one country or state to another and even from one time to another as its rate varies with respect to time and area. Demographically it is a determinant of change in population along with the fertility and mortality rates. (Arnold,1992).

\section{Marital Life and Migration}

The common problems that wives of the migrants face are loneliness, delivered responsibilities, and improved tension for conversation. Moreover, they face mental strains when their husband left them at their locale place. The wife feels lonely and sexually disturbed in case of recent marriage. Chee (2003) draws the conclusion in her founding's that marital members of the family between couples had been disturbed for separation by distance. Consequently, a few couples experienced conflict and emotional distance, divorce, and further marital affairs, others really developed more potent emotional ties for the duration of their separation. One more research performed by Thomas et al. (2003), they said in the country like UK, China and India, the general public of wives reported that the absence of their spouses had resulted numerous issues, along with loneliness, emotional disturbance and absence of guidance for kids. communication with their husbands could be very important for the wives left at the back of; it serves to "allay fears, to keep close relationships, to enhance sea-farers' morale, to relieve pressure (on board and at home) and to keep relationships with kids." inside the context of Pakistani lifestyle, wherein women do no longer have a good deal mobility, male migration breaks down women's isolation, as their added obligations (i.e. being concerned the kids, making an investment 
cash, etc.) carry them outside the orbit of the house, which leads them towards the liberalism.

The discrepancy in traditional interference on females is clear like elder wives with grown offspring are more accommodated on migration of their mates. Correspondingly the relationships with in-laws were friendly for autonomous wives, with slight or no limitations on their everyday activities. However for younger wives, the opposite was noted as in-laws occasionally limit and interfere with their everyday activities. These limits on women, (regularly based on culture, traditions, familial and behavioral profiles) have been found in numerous studies as deterring the ends of women as well as their children in the nonexistence of their men in many developing states (Bloom et al. 2001; Brown, 1983; Gulati, 1993; and Okome, 2003).

There are numerous problem of harassment met by married women due to the immigration of their men. More often these women face social harassment in street, public space, workspace and sometime harassment in household as domestic violence. Harassment means disturbing, tormenting, pestering and include a variety of an invasive nature. It is usually assumed as conduct which bothers or distresses and it is typically repetitive. The term can be defined in law as it is conduct which seems to be threatening or distressing (Iftikhar, 2016, May 6).

Sexual harassment word came in 1960, when civil rights act of 1964 were adopted. This civil rights act included the elimination of discrimination. In 1979, developed an idea that harassment was a violation of civil rights was the idea that was developed by Catharine Mackinnon, a feminist scholar. The criteria of harassment with the workplace environment were explained by EECO (The equal Employment opportunity commission). Sexual harassment affects the feelings, emotions and personality of affected one. There are some programs that also have an important role to eradicated or minimize the Sexual harassment (Cook and Hodo, 2013).

\section{Migration and Breakdown of Marital Relationships}

Most of the researches findings indicates the high rate of divorce were because of migration, Boyle (2008). Sandell (1977) stated that Puerto Rican women are more prone to divorce when they migrated to US than those women who do not migrated. The reason behind this fact is that little social regulator in US; women become independent and can end their connection with who they are willing. The fact leads to less coming 
back from US and to settle with settle again with their old men after divorce.

The migration decision also sometime influence as a factor of the dissolution of union or divorce. Higher wages of women after their migration sometime leads to divorce as their means are no longer met by their spouses, Becker et al. (1977) founds that higher wages also suggest the migrant of women create them better opportunities in the host country and hence a divorce has little effects on their economic position. Children of husband and wife, discourages both divorce of the partner and their migration. More demographic factors probable to effect divorce and coming back from the host country take account of the period of their marriage, duration in the host country, culture of their local area, religion and, and the age at which couple get married. Religion discourages the rate of divorce as a proxy for cultural distance to the secular Dutch society it guide the ease to integrate.

\section{Shift in the Role of Wife with the Migration of Husband}

Researches analyze the migration of male member of the family and his remittance sending has a role to empower and emancipate women who left behind, because of the shift of the product role that were once played by their men. Left behind women become independent due to control over the remittances and consumed by them. Moreover, migrant's women that are left behind become more autonomous in the managing of family matters (Go \& Postrado, 1986; Gulati, 1986; Rahman, 2009).

Different researches evaluated women's role in making decision which finding are that women have increased possession over the resources, specifically migrants from overseas that sent remittances to their families. Hadi's (2001) found that Bangladeshi migrant's remittances to their homes from overseas interestingly decrease the male dominancy, while knowingly changing gender roles as decision making power shifted to women from men. Unlikely past, migrants' remittances give women more control over means which consumption change their roles. Several studies found that this control over means by wives of the migrants resulted in comfort and luxuries as they no longer perform domestic chores and hire maids for domestic chores (De Haas, 2007). General, in the non-presence of men, migrants' women become more autonomous and enjoy increased liberty in management of their household activities (Rahman, 2009). In countries like, Indonesia, India, Philippines, and the Sri Lanka proof shows that women practice improved self-confidence and 
personal development after the migration of their spouses or other male members of the family (Arnold, 1992; Lucas, 2005).

On the other side, some researchers found the facts that challenge the gender-equalizing effect of that are resultant of male member migration. Even if women get autonomy from contributing in making of decision about the different affairs of the family, possession over remittances and its consumption and become the head of the family, this autonomy is not long lasting and vanished once husbands or male migrant of their family get back to their country of origin. In spite of the male member in abroad, some time, male migrants still have control over the remittances, its consumption and have the decision making power about their families from the very long distance. Moreover, certain studies found that taking the numerous roles and extra duties of transitory household head, decision making power and principal family laborer doesn't essentially imply that women's reproductive role is shifted to other roles, but physical and expressive problems might be larger for them (Arnold, 1992; Arnold and Shah, 1984; De Haas, 2007; Hadi, 2001).

\section{Objectives}

1. To study the social and psychological effect on left behind women/marital status

2. To suggest policy recommendations on the basis of study findings.

\section{Method}

The present study was conducted to probe out the sociopsychological effects on left behind women in four selected union council of district Buner. A sample size of 367 respondents were randomly selected in light of the criteria devised by Sekaran (2003). A comprehensive interview schedule, based on Likert scale was constructed and served for collecting the relevant information. The data was presented in the percentages along with ascertaining the relationship between independent variable namely (socio-psychological effects) with the quality of life of left behind families (Dependent Variable) by indexing and cross tabulating to ascertain the relationship through the application chi-square test statistics.

PESHAWAR JOURNAL OF PSYCHOLOGY AND BEHAVIORAL SCIENCES, 2017, VOL. 3, NO. 1, 95-104 


\section{Results and Discussion}

\section{Sociopsychological ffect on left behind women}

According to table majority $53.1 \%$ of the respondents told that wives of emigrants faced loneliness. These findings are synonymous with the conclusion of (Thomas et al, 2003) that the absence of their spouses had resulted numerous issues, along with loneliness, emotional disturbance and absence of guidance for kids. Moreover, 54.8\% respondents told that there was more tension in left behind families. These results were similar with the findings of (Chee, 2003) that marital relationship between couples had been disturbed for separation by distance. Furthermore, 58.6\% respondents told that basic needs like emotional needs were not fulfilled. These outcomes are in line with the view of (Thomas et al, 2003) that wives feel emotional disturbance in the absence of husband in case of emigration.

In addition, 54.4\% respondents told that conflict has been develop between spouse. These findings are in line with results of (Chee, 2003) that couples experienced conflict and emotional disturbance in in case of emigration. Majority $46.3 \%$ of the respondents told that, the emigration of husband force wives to leave the houses for purchasing of daily need goods. Moreover, $54.8 \%$ respondents said that there was more liberalism in emigrants families.These findings are in line with (Thomas et al, 2003) that women have no more restriction on their mobility from the house, male migration breakdown women isolation and added their further obligations/responsibilities (i.e. being concerned the kids, making an investment cash, etc.) carry them outside the orbit of the house, which leads them towards the liberalism. Furthermore, 58.6\% respondents told that in laws started interference in female outside activities. The outcomes are similar with the findings of (Bloom et al, 2001) that in-laws occasionally limit and have interference with their everyday activities of migrants wives .Majority $79.0 \%$ respondents mentioned that there no rise in the rate of divorce after emigration. However, these results are not in line with (Chee, 2003) that marital life of members of the family become disturbed for separation by distance. Consequently, a few couples experienced conflict and emotional disturbance, divorce, and further marital affairs.

In addition, $51.5 \%$ respondents told that, emigrant's wives were discriminated by in laws. while $41.1 \%$ of the respondents were disagree and the remaining $7.4 \%$ of the respondents express their view in don't 
know. The results are same with the view of (Iftikhar, 2016) stated that there were numerous problem of harassment met by married women due to the emigration of their men. More often these women face social harassment in street, public place, workplace and sometimes harassment in household as discrimination and domestic violence.

Table 1

Socio-Psychological Effects on Left Behind Women

\begin{tabular}{|c|c|c|c|c|}
\hline Attributes /Statement & Agree & Disagree & Don’t know & Total \\
\hline $\begin{array}{l}\text { Wives of emigrants } \\
\text { face loneliness }\end{array}$ & $189(51.5) 8($ & $36(23.4)$ & $92(25.1)$ & $367(100)$ \\
\hline $\begin{array}{l}\text { There is more tension } \\
\text { in left behind families }\end{array}$ & $282(76.8) 5 \varepsilon$ & $58(15.8)$ & $27(7.4)$ & $367(100)$ \\
\hline $\begin{array}{l}\text { Basic needs like } \\
\text { emotional needs are } \\
\text { not fulfilled }\end{array}$ & $199(54.2) 81$ & 81(22.1) & $87(23.7)$ & $367(100)$ \\
\hline $\begin{array}{l}\text { Wives of the migrant } \\
\text { husbands are disturb }\end{array}$ & 190(51.8) 1 & $156(42.5)$ & $21(5.7)$ & $367(100)$ \\
\hline $\begin{array}{l}\text { Conflict have been } \\
\text { developed between } \\
\text { wife and husband }\end{array}$ & $294(80.1)$ & $60(16.3)$ & $13(3.5)$ & $367(100)$ \\
\hline $\begin{array}{l}\text { The emigration of } \\
\text { husband force } \\
\text { wives to leave the } \\
\text { houses for buying } \\
\text { daily need goods }\end{array}$ & $189(51.5)$ & 151(41.1) & $27(7.4)$ & $367(100)$ \\
\hline $\begin{array}{l}\text { There is more liberalism } \\
\text { in emigrants families }\end{array}$ & 197(53.7) & $124(33.8)$ & $46(12.5)$ & $367(100)$ \\
\hline $\begin{array}{l}\text { In laws interfere in female } \\
\text { outside activities. }\end{array}$ & e $227(61.9)$ & $93(25.3)$ & $47(12.8)$ & $367(100)$ \\
\hline $\begin{array}{l}\text { The rate of divorce has } \\
\text { been increase after } \\
\text { emigration }\end{array}$ & $33(9.0)$ & $288(78.5)$ & $46(12.5)$ & $367(100)$ \\
\hline $\begin{array}{l}\text { Emigrant's wives are } \\
\text { discriminated by in laws }\end{array}$ & $199(54.2)$ & $141(38.4)$ & $27(7.4)$ & $367(100)$ \\
\hline
\end{tabular}




\section{Bi-Variate}

\section{Association between of Socio-psychological effects on left behind women with quality of life of left behind family}

Wives of the emigrants face loneliness was found significant $(\mathrm{p}=.018)$ with quality of life of left behind families. In addition there was more tension in left behind families was found not significant $(p=.183)$ with quality of life of left behind families. Furthermore, basic needs like emotions were not fulfilled was found significant $(p=.036)$ with quality of life of left behind families. Moreover, wives of the emigrants husbands were disturb was found significant $(\mathrm{p}=.048)$ with quality of life of left behind families. In addition, conflict have been develop between husband and wife after emigration of husband was found significant $(\mathrm{p}=.041)$ with quality of life of left behind families. Furthermore, the emigration of husband force wives to leave houses for daily need goods was not found significant $(p=.224)$ with quality of life of left behind families. While, there was more liberalism in migrant's families was found significant $(\mathrm{p}=.017)$ with quality of life of left behind families. Moreover, in laws interfere in female outside activities was found significant $(p=.036)$ with quality of life of left behind families. Furthermore, the rate of divorce has been increased was found not significant $(\mathrm{p}=.122)$ with quality of life of left behind families. In addition, emigrants' wives were discriminated by in laws was found significant $(\mathrm{p}=.037)$ with quality of life of left behind families.

Table 2

Association Between Socio-Psychological Effects on Left Behind Women and Quality of Life of Left Behind Families

\begin{tabular}{|c|c|c|c|c|}
\hline \multirow[t]{2}{*}{ Statement } & \multicolumn{3}{|c|}{$\begin{array}{l}\text { Quality of life of left behind } \\
\text { families }\end{array}$} & \multirow[t]{2}{*}{$\begin{array}{l}\chi^{2} \text { and } \\
\text { Sig } \\
\end{array}$} \\
\hline & Yes & No & Uncertain & \\
\hline \multicolumn{5}{|c|}{ Wives of emigrants face loneliness } \\
\hline Yes & $113(30.8 \%)$ & $44(12.0 \%)$ & $32(8.7 \%)$ & \multirow{3}{*}{$\begin{array}{l}\chi^{2}=11.94 \\
p<.01\end{array}$} \\
\hline No & $56(15.3 \%)$ & $26(7.1 \%)$ & $4(1.1 \%)$ & \\
\hline Uncertain & $47(12.8 \%)$ & $25(6.8 \%)$ & $20(5.4 \%)$ & \\
\hline \multicolumn{5}{|c|}{ There is more tension in left behind families } \\
\hline Yes & $166(45.2 \%)$ & $78(21.3 \%)$ & $38(10.4 \%)$ & \multirow{3}{*}{$\begin{array}{l}\chi^{2}=6.23 \\
\mathrm{p}>.05\end{array}$} \\
\hline No & $37(10.1 \%)$ & $9(2.5 \%)$ & $12(3.3 \%)$ & \\
\hline Uncertain & $13(3.5 \%)$ & $8(2.2 \%)$ & $6(1.6 \%)$ & \\
\hline
\end{tabular}




\begin{tabular}{|c|c|c|c|c|}
\hline \multicolumn{5}{|c|}{ Basic needs like emotional needs are not fulfilled } \\
\hline Yes & $117(31.9 \%)$ & $49(13.4 \%)$ & $33(9.0 \%)$ & $\chi^{2}=10.27$ \\
\hline No & $54(14.7 \%)$ & $23(6.3 \%)$ & $4(1.1 \%)$ & \multirow[t]{2}{*}{$\mathrm{p}<03$} \\
\hline Uncertain & $45(12.3 \%)$ & $23(6.3 \%)$ & $19(5.2 \%)$ & \\
\hline \multicolumn{5}{|c|}{ Wives of the migrant husbands are disturb } \\
\hline Yes & $126(34.3 \%)$ & $41(11.2 \%)$ & $23(6.3 \%)$ & \multirow{3}{*}{$\chi^{2}=9.60$} \\
\hline No & $78(21.3 \%)$ & $48(13.1 \%)$ & $30(8.2 \%)$ & \\
\hline Uncertain & $12(3.3 \%)$ & $6(1.6 \%)$ & $3(.8 \%)$ & \\
\hline \multicolumn{5}{|c|}{ Conflict have been developed between wife and husband } \\
\hline Yes & $172(46.9 \%)$ & $81(22.1 \%)$ & $41(11.2 \%)$ & \multirow{3}{*}{$\chi^{2}=9.93$} \\
\hline No & $36(9.8 \%)$ & $9(2.5 \%)$ & $15(4.1 \%)$ & \\
\hline Uncertain & $8(2.2 \%)$ & $5(1.4 \%)$ & $0(.0 \%)$ & \\
\hline \multicolumn{5}{|c|}{$\begin{array}{l}\text { The emigration of husband force wives to leave the houses for buying daily need } \\
\text { goods }\end{array}$} \\
\hline Yes & $121(33.0 \%)$ & $40(10.9 \%)$ & $28(7.6 \%)$ & \multirow{3}{*}{$\begin{array}{l}\chi^{2}=5.68 \\
p>.05\end{array}$} \\
\hline No & $79(21.5 \%)$ & $48(13.1 \%)$ & $24(6.5 \%)$ & \\
\hline Uncertain & $16(4.4 \%)$ & $7(1.9 \%)$ & $4(1.1 \%)$ & \\
\hline \multicolumn{5}{|c|}{ There is more liberalism in emigrants families } \\
\hline Yes & $129(35.1 \%)$ & $40(10.9 \%)$ & $28(7.6 \%)$ & \multirow{3}{*}{$\begin{array}{l}\chi^{2}=12.07 \\
p<.01\end{array}$} \\
\hline No & $68(18.5 \%)$ & $39(10.6 \%)$ & $17(4.6 \%)$ & \\
\hline Uncertain & $19(5.2 \%)$ & $16(4.4 \%)$ & $11(3.0 \%)$ & \\
\hline \multicolumn{5}{|c|}{ In-laws interfere in female outside activities. } \\
\hline Yes & $148(40.3 \%)$ & $49(13.4 \%)$ & $30(8.2 \%)$ & \multirow{3}{*}{$\begin{array}{c}\chi^{2}=10.29 \\
p<.03\end{array}$} \\
\hline No & $44(12.0 \%)$ & $32(8.7 \%)$ & $17(4.6 \%)$ & \\
\hline Uncertain & $24(6.5 \%)$ & $14(3.8 \%)$ & $9(2.5 \%)$ & \\
\hline \multicolumn{5}{|c|}{ The rate of divorce has been increase after emigration } \\
\hline Yes & $23(6.3 \%)$ & $5(1.4 \%)$ & $5(1.4 \%)$ & \multirow{3}{*}{$\begin{array}{l}\chi^{2}=7.27 \\
p>.05\end{array}$} \\
\hline No & $169(46.0 \%)$ & $80(21.8 \%)$ & $39(10.6 \%)$ & \\
\hline Uncertain & $24(6.5 \%)$ & $10(2.7 \%)$ & $12(3.3 \%)$ & \\
\hline \multicolumn{5}{|c|}{ Emigrant's wives are discriminated by in laws } \\
\hline Yes & $130(35.4 \%)$ & $41(11.2 \%)$ & $28(7.6 \%)$ & \multirow{3}{*}{$\begin{array}{l}\chi^{2}=10.2 \\
p<.03\end{array}$} \\
\hline No & $89(18.8 \%)$ & $48(13.1 \%)$ & $24(6.5 \%)$ & \\
\hline Uncertain & $17(4.6 \%)$ & $6(1.6 \%)$ & $4(1.1 \%)$ & \\
\hline
\end{tabular}

\section{Conclusion and Recommendations}

The study concluded that wives of emigrants faces loneliness; there was more tension in left behind families; basic needs like emotional needs were not fulfilled; conflict has been develop between spouses; emigration of husband force wives to leave the houses for buying of daily needs, goods; in laws start interference and objections on female outside activities. Moreover, the rate of divorce has not been increased after emigration; emigrant's wives were discriminated by in laws. It is recommended that migrant should increase visiting home or shift their family to abroad to reduce tensions and conflict. 


\section{References}

Arnold, F. (1992). The contribution of remittances to economic and social development. In: Kritz MM (ed.) International Migration Systems: A Global Approach. Oxford: Clarendon Press.

Bloom, S. S., Wypij, D., \& Gupta, M. D. (2001). Dimensions of women's autonomy and the influence on maternal health care utilization in a north Indian city. Demography, 38(1), 67-78.

Boyle, P. J., Kulu, H., Cooke, T., Gayle, V., \& Mulder, C. H. (2008). Moving and union dissolution. Demography, 45(1), 209-222.

Chee, M. W. (2003). Migrating for the children: Taiwanese American women in transnational families. Wife or Worker? Asian Women and Migration, 137-56.

De Haas, H. (2007). The impact of international migration on social and economic development in Moroccan sending regions: a review of the empirical literature. International Migration Institute, Working Paper, 3.

Elbadawi, I. A., de Rezende Rocha, R., \& Mundial, B. (1992). Determinants of expatriate workers' remittances in North Africa and Europe (No. 1038). Country Economics Department, World Bank.

Go, S. P., \& Postrado, L. T. (1986). Filipino overseas contract workers: their families and communities

Hadi, A. (2001). International migration and the change of women's position among the left-behind in rural Bangladesh. International Journal of Population Geography, 7(1), 53-61.

Javid, M., Arif, U., \& Qayyum, A. (2012). Impact of remittances on economic growth and poverty. Academic Research International, 2(1), 433.

Rahman, M. (2009). Temporary migration and changing family dynamics: implications for social development. Population, space and place, 15(2), 161-174.

Thomas, M., Sampson, H., \& Zhao, M. (2003). Finding a balance: companies, seafarers and family life. Maritime Policy \& Management, 30(1), 59-76. 